\title{
Scripting and Digital Fabrication in Artisanal Processes: The Case of South America
}

\author{
PABLO C. HERRERA
}

Universidad Peruana de Ciencias Aplicadas

Since the last decade, South America experiments the implementation of scripting and digital fabrication, along with architects interested in establishing synergies with artisans, inside the context of cases linked to experiences a) formative, b) academic, and c) practical. The objective of this research was to identify processes for implementation and improvement of tools and instruments, analyzing the relationship and ways in which local traditions are being preserved, while being customizable and transcending into global markets.

\section{INTRODUCTION}

Considering that the renaissance of craftsmanship proved to be a promise for Latin America ${ }^{1}$, we documented experiences, implementation patterns, origins and results of a selection of proposals that link artisanship and digital fabrication in their regional context.

According to Oxford Dictionary, artisan is "a worker in a skilled trade, especially one that involves making things by hand". Likewise, the Dictionary of the Real Academia Española describes an artisan as somebody who "exercises a purely mechanical art or skill." Finally, Sennett's artisans are, in a very broad sense, computer programmers, physicians or artists, carpenters, orchestra directors or weavers ${ }^{2}$. For Sennett, "all craftsmanship is rooted in a deeply developed activity." ${ }^{3}$

The first aim was to define the differences between the Latin American and specific the South American artisan and his equivalent in countries leading the use of emergent digital technologies. The second aim was to identify in retrospective how fabrication and programming contribute to the region's craftsmanship, overcoming previous technologies associated solely to representation and visualization. The third aim allowed the identification of a future research path, documenting the people who transformed the meaning of the artisanal object and took it to a different cultural system, by taking traditions, and using and adapting material, to integrate them to digital fabrication processes. This is a global tendency maximized by the technologies to produce and modify designs, named neo artisans.
CRAFTSMANSHIP IN THE GLOBAL SOCIETY OF THE 21ST CENTURY

Craftsmanship linked to the digital as an agent of change in the 21st century has been studied in the Making Futures conferences since $2009^{4}$. They discussed the tendency, defined by two types of users. Ferris describes the first type as specialized and directly or indirectly integrated to the Maker movement. The second type, instead, is somebody who took his practice to a professional level with DIY projects, as

“a story of grass roots DIY, feminist 'craftivists', voluntary material simplicity advocates, and allied campaigners for local recycling and make and mend. All buoyed by broader alternative initiatives like the transition movement, urban farming, local markets and craft fairs, and reaching out to new audiences through internet websites, blogs, Facebook interest groups, and YouTube." 5

We cannot yet generalize these types of users to the Latin American case, because the maker movement is not a frequent activity (only three countries in South America have had a Mini Maker Faire in our region: in Chile (2013), Colombia (2015) and Argentina (2016). Technological limitations to access, referred in this research, are the main reason why we couldn't find more users of the second type.

From a European perspective, crafts techniques' inclination toward the digital is explained because its production processes moved towards fabrication. ${ }^{6}$ Bunnell ${ }^{7}$ documented the used of CAD-CAM technologies in pottery with the experiences of doctoral theses and academic works, linked to European universities. In addition, Bunnell ${ }^{8}$ identified CAD programs and equipment such as CNC, Laser and 3D printers, used in pottery, textile and jewelry, but with no references to the South America context. In USA, other cases were discussed in ACSA conferences between 1996 and 2014 in relation with craft and architecture, but in the field of arts and crafts movements and its relation with digital technologies. Even though these experiences are important as implementation models, it was not possible to find similar references in the specific case of our region, except for the general work (but not directly associated to digital technologies) of Borges ${ }^{9,10}$. This is the reason why firstly we defined the concept of artisan in our region, and then identified our cases. 


\section{ARTISAN AND CRAFTSMANSHIP IN SOUTH AMERICA}

Borges sustains that "in Northern countries crafts techniques are practiced by educated people who see in this activity a form of selfexpression." 11 In Latin America, on the contrary, this activity is not just performed both in the countryside and also in peripheries and informal settlements of larger cities, where, collectively, artisans face multiple adverse conditions. This makes short-term implementation very difficult. José Sabogal said that "the artisan is one who disposes freely of his workforce, not somebody who works for a patron or contractor"12, talking about those recruited in the poorest areas of the city, in the squatter settlements around Lima and other South American cities, to work for an entrepreneur owning a factory and producing something announced as craftsmanship ${ }^{13}$. In addition, Sabogal says, "artisan is somebody who basically creates and recreates in the elaboration of his crafts, being more than a mere producer."14. Popular traditions defined artisanship in Latin America:

"An economic and cultural activity, destined to the elaboration and production of goods, completely by hand or with the help of manual tools, or even mechanical means (...) employing raw materials from the site and related to a specific production location."16

This is a definition lately used in many countries with a legal scope: in Peru, by law $29073^{17}$ through the Ministry of Foreign Trade and Tourism, in Chile by the National Council for Culture and Arts $^{18}$ and in Brazil through the Republic Presidency ${ }^{19}$. An exceptional case for the region and its relationship with digital technologies was Artesanías de Colombia S.A., created by the Ministry of Trade, Industry and Tourism in $1964^{20}$. By the end of the 1990s, the alliance between designers and artisans was implemented in projects such as the Design Laboratory. The goal was innovate and improve the research and developing of products with technologies, and boost human talent, promoting a methodology assisted by computer. "Based on the horizontal interaction between artisan and designer, which allowed to encourage the artisan's creative processes, visualize and contextualize the alternatives offered by the product in practice, and facilitate the creation and recreation mechanisms of the cultural imaginary" ${ }^{21}$. Similar models were adopted in other countries from South America, but as selfmanaged experiences and not as a national policy. This was a guided process that only automatized representation processes over others such as fabrication, as analyzed in this research.

\section{ARTISANAL OBJECT}

Borges explains that uniformity and standardization in an industrial product is different from that of artisanship, because the latter is never alike ${ }^{22}$. Castrillón says, "a popular piece, even if worked in series, never turns out identical to the others". It is the "result of a series of additions that, with time, sum up to the community." ${ }^{23}$. Thus, scripting and visual programming facilitates modifying the possibilities of form and construction of objects, when code is used in the process. Digital fabrication reinforces the production at a lesser cost, because the cost of a part or component "is based on the machine's time, not shape or variety of parts, so there is no surcharge for complexity or difference." 24 It leaves an open possibility not only for many artisans, architects or designers, but also for a broad variety of objects.

Another situation artisan objects is that this production has always been "purchased by people who wanted inexpensive items mainly because of their use value, or they were bought by intellectuals, professionals and tourists" ${ }^{25}$. About the objects in the practice, Rengifo ${ }^{26}$ underlines Sabogal's posture ${ }^{27}$ on the demand of "metropolitan" countries that detract the real scope of the artisanal object. In relation to education, Borges says, "design schools also prepared their students for a serial production market, typical of large developing manufactures." 28 García Canclini adds, "artisanal objects produced by indigenous or countrymen groups circulate around society and are taken by urban areas, tourists, whites and non-indigenous population." 29

\section{LEARNING CRAFT AND ARTISANAL TECHNIQUES}

From a South America perspective, Borges says that in the northern hemisphere craftsmanship techniques are learned in university classes $^{30}$. Rengifo explains that learning of "artisanship is unschooled, and does not use manuals; it happens in the very socializing process of children, such as learning how to dance." ${ }^{31}$ From the point of view of who produces and acquires the ability, Acha says that artisanship is learned empirically; arts, academically; and design in university training. ${ }^{32}$ Digital fabrication overcomes those differences, since it allows the artist or designer to take a tradition in order to transform the original intention of a unique product in a series.

\section{METHODS}

From the accumulated research on digital fabrication between 2004 and 2014 , Latin America is $11 \%$ of the world's total ${ }^{33}$. This does not include self-managed initiative, like some of the ones presented in this research. We also used a previous study carried on in Perú and Chile ${ }^{34}$ and analyzed the production of Fab Academy in South America, established in 2009 (the region has a total of 50 representing almost 8\% of the world's total) and other associates of the Maker Movement. Finally, we checked the results of thirty regional experiences on digital fabrication ${ }^{35}$ and reviewed regional and national policies, in order to recognize the alliance between artisans, architects, digital fabrication and programming. The selection of all cases is presented in this research.

\section{CASE STUDIES}

Amongst a first group of architects, we identify cases linked to experiences a) formative, b) academic, and c) practical. Diverse results were considered, directly linked to digital fabrication (formative and academic) and just one case that integrated fabrication and visual programming (practice). Aiming to establish a tendency, we identified a second group of experiences named a) non-artisanal experiences, with industrial designers why transformed the traditional features of the object. 


\section{CASE STUDY A}

\section{a) Formative experiences}

Are self-managed in most cases, and are supervised or inside a specialized program. There is more freedom of models, since initiatives start with participants and are maximized by the program. Fab Academy (http://fabacademy.org/) is an educational program between January and June, in eighteen subjects and a final project. It was created by MIT and IaaC (Institud d'Arquitectura Avançada de Catalunya) to promote digital fabrication. It opened in 2009 and started in 2010. Peru and Ethiopia started the project, with founding from the Spanish government ${ }^{37}$. From this formative experience we identified different cases, in Peru and México, related to knitting machines. There is also an initiative in Costa Rica and a group in Colombia, looking in different non-central communities the socialization with digital fabrication.

Fab Academy 2012. In FabLab UNI, architect Walter Gonzales Arnao fabricated a loom that reduced costs and production times. Known as fabable loom, this object is produced in one hour and costs around US\$100.00

Experiments in a class on looms on the School of Architecture, Urbanism and Arts at Universidad Nacional de Ingeniería in 2011 was the origin of this project. The projects designed by Gonzales focused in three objects: a) the miniloom (with acrylic cut with laser), b) the back strap loom, and c) the treadle loom ( 9 cardboard pieces pressed together, cut with a CNC, optimizing up to $60 \%$; uses several materials and is made of around 30 pieces) (Figure 1)

Gonzáles won the Design for Development award for his treadle loom and for creating a technology that improves the life of vulnerable or poor people, as detailed by the bases of the 4a Bienal Iberoamericana de Diseño in Madrid. In October 2015 this invention was patented in Peru, under the name "telar de cintura andino mejorado". Different versions of the product were used by artisans such as Master Oscar Salomé Rojas, known as Meritor Cultural Personality in 2015 for his contribution and research on knitting using a backstrap loom.

Gonzales' projects were also part of global educational
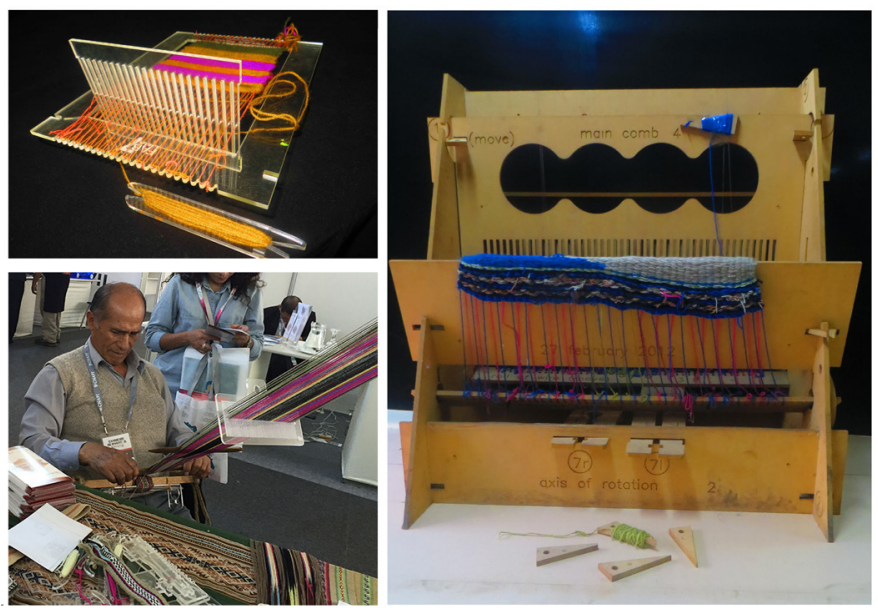

Figure 1: Top left: miniloom ; Bottom left: Artisan Oscar Salome using the andian backstrap loom; Right: Treadle loom. Images courtesy of W. Gonzales Technology implementations, like the Fab Loom project replicated in MediaLab Prado in Madrid (2014). This workshop took the conditions of open source, presented at the Global Fab Awards at Fab10, in Barcelona. The idea was to replicate the loom in several FabLab in Spain.

Similar experience creating looms was the case the architect Gonzalo Pérez at Fab Academy 2013 in the FabLab México. Pérez, worked with a poor indigenous community of women in Chiapas dedicated to knitting ${ }^{36}$. A different case to that of Gonzales, who already had experience with the problem and thus fabrication resulted in a specific solution. In the best scenario, results lead to understand the nature of the process, but with limitations in the result

Artesanías Digitales FabLatNetwork. This network was created in the 7th World FabLab Congress (Lima, Perú, 2011) and starts its public activities online in 2013. Its initiative related to artisanship consolidates at the FabLAT network in 2016. It includes packing design workshops, and direct support to artisans in an alliance with so-called neo artisans instead makers or fabbers, people with skills in digital fabrication working in a FabLab.

\section{b) Academic experiences}

Aconcagua FabLab. (http://www.aconcaguafablab.cl/). It is a mobile laboratory of digital fabrication, developed by the School of Architecture at Pontificia Universidad Católica de Valparaíso (Chile).

It is located in public spaces and is focused on micro and small entrepreneurs in craftsmanship, traditional trades, design and architecture. It facilitated the technological upgrade in processes and local products for 12 communities in the region of Valparaíso. It was founded by the Fondo de Innovación para la Competitividad from the Gobierno Regional de Valparaíso between 2014 and 2015

\section{c) Practical experiences}

In this century, the implementation of scripting and programming in USA architecture started with fabrication and then moved to design. In South America, the opposite happened, because the costs of equipment privileged design, and thus fabrication came years later. In Europe, self-made 3D printers have been used for several years. That

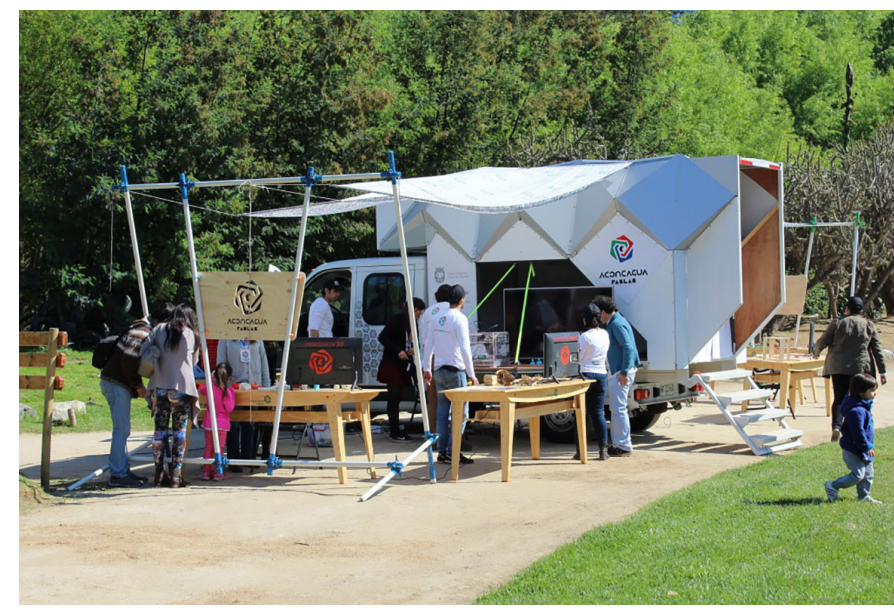

Figure 2: Mobile Laboratory Aconcagua FabLab. Image by the authors

Cross-Americas: Probing Disglobal Networks 
is the case of Jonathan Keep, who adapted a Delta printer and says, "The form is in the code". Keep argues that "digital computation is offering very new ways of generating ceramic form and that with time this 'new' will become part of tradition. Pottery has always reflected the technology of its time so for me it makes absolute sense to generate my work in computer code and then make it using 3D printing technology $y^{38}$. This observation is not isolated. In South America, explorations have led to the recovering of original proposals instead of adaptations.

great things to people, gt_2P (www.gt2p.com/). In Chile, this architect's studio has a proposal that goes beyond code, fabrication and art. It is a parametric design and digital fabrication office, founded in 2009 by an initiative of Guillermo Parada, participant of the first workshop of written programming at Universidad de Chile in 2006. ${ }^{39}$

gt_2P explained in 2014 that the collection Losing my America (Figure 3) was born with the aim to identify techniques and artisans with a high sociocultural and economic value, with the potential for collaboration through exchange in practice, aiming for the systematization of their craft techniques and the reinforcement of local economies. ${ }^{40}$

Under the premise "more parametric, less digital", the project of 2013 catenary pottery printer (Figure 4) aims to explore non-digital parametricism. gt_2P introduces the term digital crafting. "This means mixing digital technology (data managing, systematization of variables, digital production) and traditional techniques (handmade, traditional industry, local procedures and local materials)." ${ }^{\prime 41}$ The processes integrate generative algorithms in architecture, art and design, which make it easy to resize to different families of products. They create the DNA with parametric rules that allow the client to define
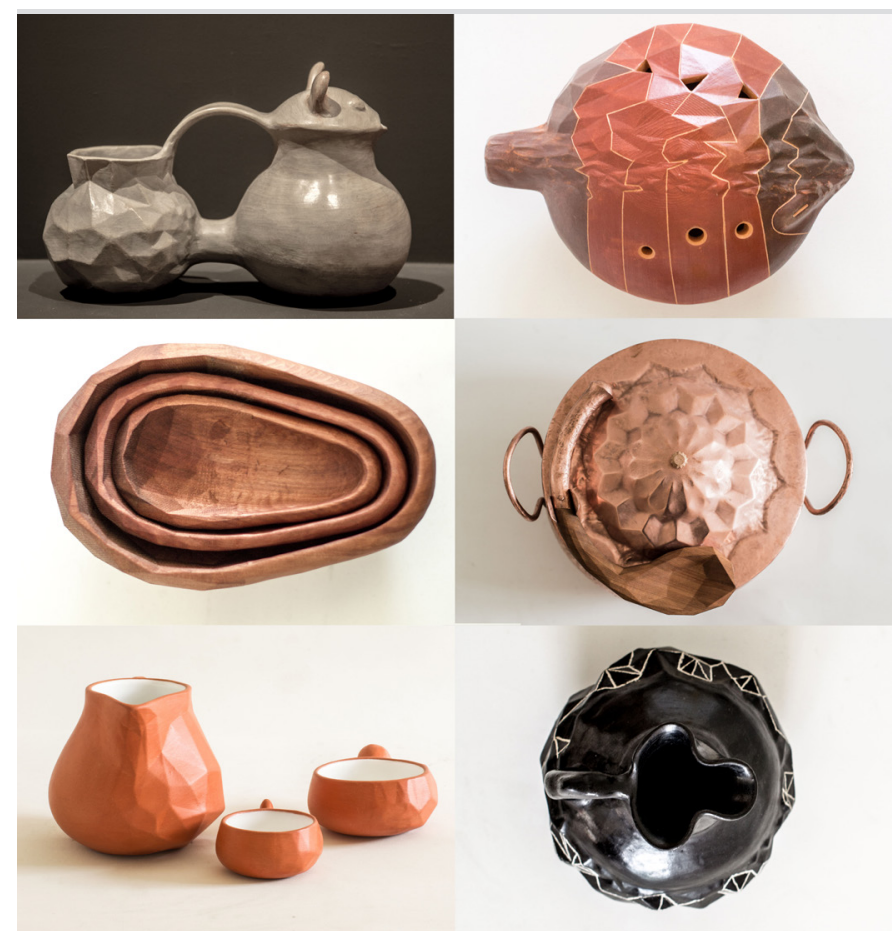

Figure 3: gt_2P with artisans. Images courtesy by the authors. . the result for each product. The ceramic objects they produce are based on the idea of computer aided craftsmanship.

Architects no longer associated to gt_2P continue to implement Digital Crafting. That's the case of Juan Pablo Ugarte, who studied at GSD in Harvard, exploring "how the artisan's creativity and his productive logics can help producing work fluxes in design and digital fabrication, where knowing the material actively informs the design." $" 42$

\section{CASE STUDY B}

\section{a) Formative experiences}

García Canclini ${ }^{43}$ argues that social processes are not something that appears equally. Therefore "an object can transform through its uses and social re-appropriations. (...) in that sense it is ethnocentric to think that the sense of craftsmanship has been degraded." Starting with the regional definitions, we detected experiences of adaptation of artisanal objects. Variations included material, original shape, process and morphology. This was possible only because digital fabrication allows a minimum very precise and modifiable production. In these cases, the intervention was between industrial designer and object, and not the artisan.

Orígen Peregrino (http://www.origenperegrino.com) is a Peruvian design studio that joins agency TAG Estudio Gráfico with the work of industrial designer Lau Toyosato. Both develop pieces that maintain the essence and meaning of their origin, creating an artistic piece, a traditional mask used in the Diablada dance from Bolivia y Perú.

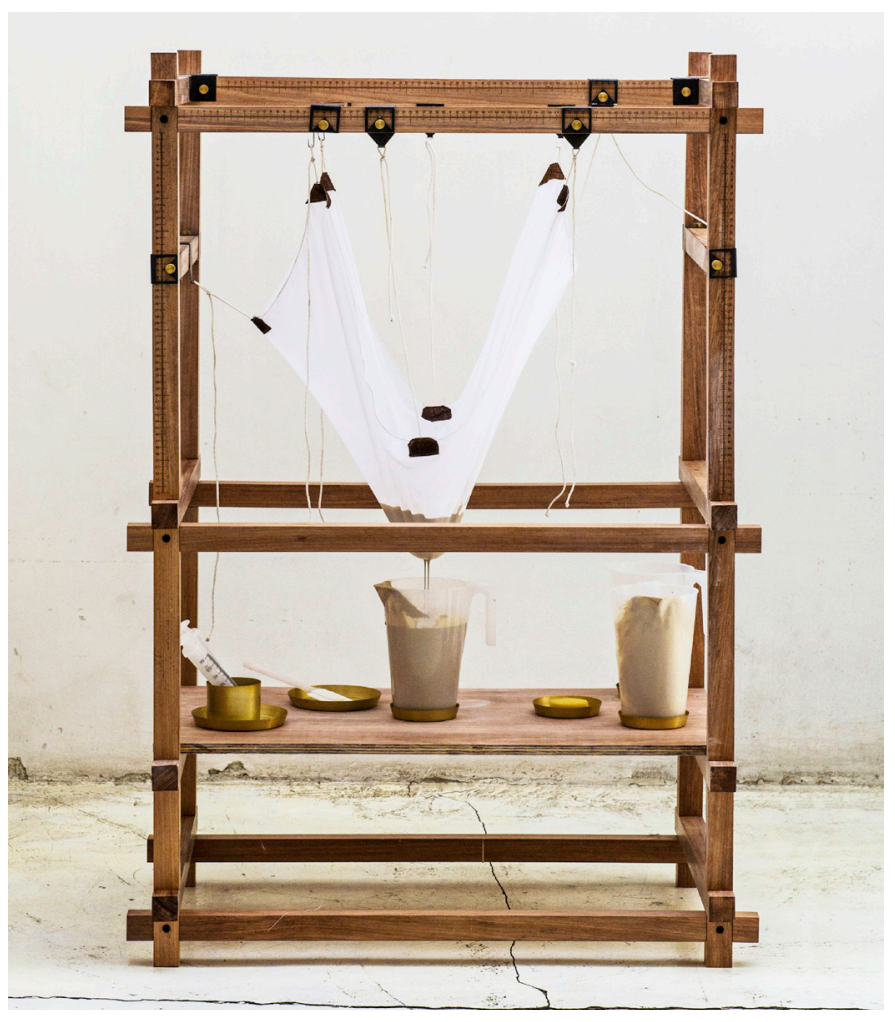

Figure 4: Catenary pottery printer. Images courtesy of gt_2P.. 
Victor Freundt. Peruvian industrial designer received the first training at Fab Academy at laaC (2009) as part of a project for the implementation of the FabLab network in South America. In 2010 he obtained the first prize in the Allpa Perú competition, on innovation in artisanal design. His product starts with a traditional artisanal pottery piece from Puno, the Pucará bull. Through piecing it like a puzzle using a technique common to the work in CNC, he managed so synthetize in few pieces an object that can also be used like a trunk.

In both cases, even though the origin comes from artisanship, the results are transformed for another reality and use; their promoters describe it as traditional artisanship "with a very contemporary touch". But, these Peruvian cases are not an exception. Other examples in our region were exposed in exhibitions such as New Territories: Laboratories for Design, Craft, and Art in Latin America (Albuquerque Museum), which "surveys the innovative, cross-disciplinary collaborations and new directions in creative production that have been occurring throughout Latin America since 2000", where craft, art and design have transcended their former identities. ${ }^{44}$

\section{CONCLUSIONS}

The most pressing matters in the implementation of craft techniques to artisans are common to the region, especially because "there is a difficulty in the area to access to digital platforms." ${ }^{\text {"A5 }}$ Also, "Technological level applied to products and processes is limited; there is resistance to training, to applying what has been learned and to modify their work, with difficulty to access Internet." ${ }^{\prime \prime 6}$. This requires the implementation of creative collaborative platforms and networks for not only working, but also learning and socializing, in order to better guide a sustainable collaboration between designers and artisans.

In the case of formative experiences, one of the difficulties observed at Fab Academy, was the short time to create, make and modify the projects. Social proposals that could make a real impact have a complex transition to reality because of the many technical problems that the participant has to face. Not being a specialist in the chosen problem and having to learn new production techniques results in partial results or being unable to comply with the initial objectives.

Parallels between the meaning of artisan and artisanship in South America allow classifying the difference between enforcing the artisanship tradition and using it as reference or analogy. The work of architects (Case Study A) centered in producing a real alliance and intense collaborative work, contrary to the cases produced by industrial designers or neo artisans (Case Study B) who adapted existing traditions to their own needs.

Industrial design had the chance to be the first integration link with artisanship, given its similarities of approach to the design of objects and scale, but it was architecture that showed the integration with revitalizing the work of artisans. This impulse has its origins in the coming back of grad students to their countries of origin, or in the training received from foreign academics, which now shows meaningful results. This groups of architects had the opportunity to experiment with fabrication ${ }^{47}$, allowing the acquisition of skills that they applied in a practical and academic context, in collaboration with artisans.
In Case Study A, digital fabrication allowed to produce cheaper machines that were also more précised and made of less parts, with the possibility of replacing them, and, in time, customize their dimensions according to users' preferences (Peruvian case) as can be seen in Figure 1.

Case studies will not be modifiable if the memory stays in the object. gt_2P showed that programming makes flexible not just the changes, but also every part of the process up to the final object. Scripting and programming guided by specialists, common to architects familiarized with Rhinoscript, Python, Grasshopper or Dynamo allows saving the process in the shape of the object, preserving the tradition of representation and its future modifications (Chilean case).

This research reveals in the Case Study A, that the use of traditional materials was maintained, the pieces continued to be unique and, at the same time, customizable by final users. On one hand, fabrication was used to automatize processes and maintain the traditional character of the object; on the other, techniques used by architects were improved, and are now used in their own processes. It has been a laboratory that allowed understanding from the object and assimilates a tradition that could be taken to architectural scales, a necessary vision that could allow the equilibrium between technology and quality of life.

The case study shows initial models that could migrate to other contexts, especially emergent populations, strengthening roots of identity and culture, which could be lost with the urbanization and the artisan's migration to cities. The possibility of using Mobile $\mathrm{Labs}^{48}$ to approach technologies to people with limited reach to technologies, as shown in the case of Valparaíso in Chile, creates opportunities for reproduction not only locally, but also in the implementation of a model for the region.

All these experiences could change the history of contemporary design in the region while empowering local traditions. It was found that architects and artisans revitalized an identity and cultural tradition without losing the originality of their proposals. This could enhance the possibilities of access in the artisanship sector, which in most cases refuses to pass the limits of their traditional tools.

Considering that, South America started using emergent technologies in academy and not in practice as in the North of the planet ${ }^{49} \mathrm{We}$ conclude that the effect of implementing programming and digital fabrication for the past decade in architectural schools (and not so much in industrial design schools) allowed for the students' initiatives (now professionals) grow with the scope of improving other people's quality of life using technologies that were too expensive on previous years. This reduced the cost of buying new equipment, which favors not only the artisan but also the economy. This also serves as a learning model in which technology can and should boost our Habits of Craft, Here, There and Everywhere.

\section{ENDNOTES}

1. Borges, Adele. Craft revitalization as a change agent in Latin America. Making Futures Journal 3, 11-14. Retrieved from http://www.plymouthart.ac.uk/documents/Adelia_Borges_-_Keynote.pdf, 2015, p.14.

2. Sennett, Richard. The Craftsman. New Haven: Yale University Press, 2008. p.20.

3. Sennett, op. cit., p.32.

4. Ferris, Malcolm. The crafts in the context of emerging global sustainability agendas, Making Futures Journal. 1. Retrieved from http://mfarchive.plymouthart.ac.uk/ 
journalvol1/papers/Making\%20Futures\%20Paper\%20Editor\%20Introduction.pdf, 2009, p. i.

5. Ferris, Malcolm. The returns of crafting a Post-Global in the context of emerging global sustainability agendas, Making Future Journal 3. Retrieved from http:// mfarchive.plymouthart.ac.uk/journalvol3/assets/making_futures_editors_introduction_by_malcolm_ferris.pdf, 2013, p. 5.

6. Feringa, Jelle. Implicit Fabrication, Fabrication Beyond Craft, The Potential of Turing Completeness in Construction. ACADIA 32, 383-390. San Francisco: California College of the Arts. Retrieved from http://papers.cumincad.org/data/ works/att/acadia12_383.content.pdf, 2012, p. 384.

7. Bunnell, Katie. The Integration of New Technology into Ceramic Designer-Maker Practice, PhD Thesis published on CDROM, The Robert Gordon University, Aberdeen, 1998.

8. Bunnell, Katie. Craft and Digital Technology, World Craft Council 40th Annual Conference, Metsovo, Greece, 2004.

9. Borges, Adele. Design + Craft. The Brazilian Path, Sao Paulo: Editora Terceiro Nome, 2011.

10. Borges, 2015, op. cit.

11. Borges, 2015, op.cit., p.11.

12. Rengifo, Antonio. La Artesanía en la obra de José Sabogal Wiesse. Lima: Centro de Proyectos Integrales en Base a la Alpaca, 1989, p. 88.

13. Sabogal, José. Artesano y Artesanías. Diario El Comercio. Lima, 13 de noviembre de 1974.

14. Sabogal, José. La cerámica de Piura. Quito, Ecuador: Instituto Andino de Artes Populares, 1982.

15. Rengifo, op. cit., p. 89.

16. OEA. Organización de Estados Americanos, Carta Interamericana de las Artesanías y las Artes Populares, Washington D.C., 1973.

17. DOP, Diario Oficial el Peruano, Ley 29073 del artesano y del desarrollo de la actividad artesanal, Lima, Perú, 2007.

18. CNCA Concejo Nacional de la Cultura y las Artes, Política de fomento para la artesanía 2010-2015, Valparaíso, Chile.

19. Presidência da República Law 13.180. Subchefia para Assuntos Jurídicos da Casa Civil, Brasilia DF, Brazil, 2015.

20. Duque, Cecilia; Sethi, Rithu; and Vencatachellum, Indrasen. Designers meet Artisans. New Delhi, India: Craft Revival Trust, 2005, p.70.

21. Duque, et al., op. cit., p. 73.

22. Borges, 2015, op. cit., p.14.

23. Castrillón, Alfonso. ¿Arte Popular o Artesanía? Historia y Cultura 10. Revista del Museo Nacional de Historia, 15-21. Lima, 1977, p. 19.

24. SHoP architects. SHoP Out of Practice, New York: The Monacelli Press, 2012, p.251.

25. Vargas, Gabriela. Flexible Looms: Weavers' Organizations In Chiapas, México, Urban Anthropology and Studies of Cultural Systems and World Economic Development, 28, 299-325, 1999, p.303.

26. Rengifo, op. cit., p.94.

27. Sabogal, 1974, op. cit.

28. Borges, 2015, op.cit., p.12.

29. García Canclini, Néstor. Diferentes, desiguales y desconectados. Mapas de la interculturalidad. Barcelona: Editorial Gedisa, 2004, p.34.
30. Borges, 2015, op.cit., p.11.

31. Rengifo, op. cit., p. 91.

32. Acha, Juan. In Introducción a la teoría de los diseños. México DF: Editorial Trillas, 2009, p.71.

33. Luli, Elza and Minto, Marcio. Digital Fabrication in Brazil. Academic production in the last decade. In Celani, Sperling, Franco (Eds.) 16th International Conference CAAD Futures 2015, 421-433. São Paulo. Retrieved from http://papers.cumincad. org/data/works/att/cf2015_421.content.pdf, 2015.

34. Herrera, Pablo. Digital Fabrication and Revival Craft in Latin America, 10th ICDHS 2016, Taipei, China, 2016.

35. Sperling, David; Herrera, Pablo and Scheeren, Rodrigo. Migratory Movements of Homo Faber: Mapping Fab Labs in Latin America, CAAD Futures 2015, 405-421. Sao Paulo, Brazil, 2015.

36. Herrera, Pablo and Juárez, Benito. Fabrication Laboratories: Problems and possibilities of implementation in Latin America, Fab9 Research. Yokohama, Japón, 2013.

37. Herrera, 2016, op. cit.

38. Keep, John. The Form is in the Code, Ceramics and New Technologies Symposium. Retrieved from http://www.holburne.org/planning-your-visit/whats-on/talks/ ceramics-symposium-abstract/, 2016, paragraph six.

39. Herrera, Pablo. Solución de problemas relacionados al diseño de superficies complejas: Experiencia de programación en la educación del arquitecto, 11th SIGraDi, 97-101. México DF, 2007.

40. gt_2P. Great things to People (2014). Losing my America. Retrieved from http:// www.gt2p.com/Losing-my-America-1.

41. Rosso, Annalisa. Digital Crafting with gt_2P Chilean Collective. Retrieved from https://artemest.com/magazine/new-vision/gt2p-digital-crafting.

42. GSD Harvard (n.d.). Doctoral Programs. Student Profiles. Retrieved from http:// www.gsd.harvard.edu/\#/academic-programs/doctoral-programs/ddes/studentprofiles.html.

43. García Canclini, op. cit. p.34.

44. Stokes, Lowery et. al. New Territories: Laboratories for Design, Craft and Art in Latin America. Madrid, España: Turner.

45. CNCA, op. cit. p.36.

46. DIRCETUR Dirección Regional de Comercio Exterior y Turismo - Puno. Plan operativo institucional, 2013, p.23.

47. Herrera, Pablo and Juárez, Benito, 2009, op. cit.

48. The first Mobile Fab Lab debuted in 2007 in Chicago (USA) and in 2016 the first Fab Lab Móvil from Fab Lab Veritas in Central America started to travel in Costa Rica.

49. Leach, Neil and Yuan, Phillip. Scripting the Future, Shanghai: Tongji University Press, 2012, p.9. 